\title{
НАРОДНЫЕ ИСТОКИ ОБРАЗНОГО ЯЗЫКА РУССКОЙ ЛИТЕРАТУРЫ 1
}

\author{
ВАЛЕРИЙ МОКИЕНКО \\ Санкт-Петербургский государственный университет \\ mokienko40@mail.ru \\ ORCID: 0000-0002-0264-0576
}

\section{АННОТАЦИЯ}

Русский литературный языка, как и все европейские литературные языки, представляет собой сложную систему, своеобразный «плавидьный котёл», в котором воедино слились самые раздичные стихии: «Своё и чужое», «Новое и старое», «Кодифицированное и некодифицированное», «Книжное и речевое (resp. просторечное)», «Общее и специальное» и др. Изучение каждого из этих пластов в их исторической ретроспективе и перспективе помогает понять как общие закономерности развития русского литературного языка, так и его специфику на общем европейском языковом фоне. Для истории русского языка особо актуальным является взаимодействие книжной и речевой стихий, количественные и качественные пропорции были раздичными в разные эпохи его развития. В докладе исследуется вдияние народной речи на русский дитературный язык эпохи его национального расцвета начала XIX века. Предлагается анализ известных образных выражений классиков этого времени И.А. Крылова, А.С. Грибоедова и А.С. Пушкина. Истоки таких выражений выявляются на материале составляемого автором и его соавторами (Т.Г. Никитиной и Е.К. Николаевой) «Полного фразеологического словаря русских народных говоров».

КАЮчЕВЫЕ СЛОВА: русский литературный язык, разговорная речь, язык классиков русской дитературы, народная фразеология, пословицы и поговорки.

\section{POPULAR SPEECH SOURCES OF THE FIGURATIVE LANGUAGE OF RUSSIAN LITERATURE}

\author{
VALERY MOKIENKO \\ St. Petersburg State University
}

\section{ABSTRACT}

The Russian literary language, like all European literary languages, is a complex system, a kind of "melting pot" in which the most diverse elements have merged: "The Own and the Foreign", "The New and the Old", "The Codified and the Uncodified", "The Literary and the Colloquial (resp. Common)", "The General and the Special", etc. The study of each of these layers in their historical retrospective and perspective affords to understand both the general patterns of the

\footnotetext{
${ }^{1}$ Полная редакция текста, прочитанного в кратком варианте на пленарном заседании Международной Конференции Русистов [МКР -2018] в Барселонском Университете, Барселона, 20 июня 2018 г. Исследование выполнено при финансовой поддержке РФФИ в рамках научного проекта № 17-29-09064.
} 
development of the Russian literary language and its specificity on the general European background. For the history of the Russian language, the interaction between the literary and colloquial elements is especially topical; the quantitative and qualitative proportions were different at different times of its development. The article examines the influence of popular speech on the Russian literary language of the era of its national flowering of the early XIX century. The analysis of known figurative expressions of the classics of this time (I.A. Krylov, A.S. Griboyedov and A.S. Pushkin) is offered.. The origins of such expressions are revealed on the material of the "Full phraseological dictionary of Russian folk dialects", compiled by the author and co-authors (T.G. Nikitina and E.K. Nikolaeva)

KEYWORDS: Russian Literary Language, Spoken Language, the Language of the Classics of Russian Literature, Folk Phraseology, Proverbs and Sayings.

Русский дитературный язык, как и все европейские литературные языки, представляет собой сложную систему, своеобразный «плавильный котёл», в котором воедино слидись самые раздичные стихии: «Своё и чужое», «Новое и старое», «Кодифицированное и некодифицированное», «Книжное и речевое (resp. просторечное)», «Общее и специальное» и др. Изучение каждого из этих пластов в их исторической ретроспективе и перспективе помогает понять как общие закономерности развития русского литературного языка, так и его специфику на общем европейском языковом фоне. Каждая из этих оппозиций не становится деструктивной стихией, уничтожающей языковую систему, а наоборот - динамизирует её и вливает молодое вино в её старые мехи, сшитые ещё в праславянскую эпоху. Так, оппозиция «Своё и чужое» активизировала способность русского дитературного языка активно поглощать заимствования. Благодаря этому он обогатился и старославянизмами, и грецизмами, и германизмами, а в последнее время - американизмами. И это позводило русскому языку войти в ряд развитых европейских языков, обеспечить его номинационную масштабность, расширить своё синонимическое и стилистическое пространство. Динамичность же оппозиции «Новое и старое» способствует его постоянному омоложению и оперативной модернизации. Не случайно, например, период послеперестроечных «Дихих девяностых», несмотря на все политические, экономические и социальные перипетии оказался чрезвычайно продуктивным для современной лексики и фразеологии. Недавно вышедший академический словарь «Новые слова и значения. Словарь-справочник по материалам прессы и литературы 90-х годов» (НС3-90: 1-3), изданный в 2015 году в Институте лингвистических исследований в Петербурге, по объёму занимает почти 4000 страниц, хорошо илдюстрируя открытость русского языка ко всему современному и «Чужому».

Динамизирующая роль этих и других оппозиций - не просто некий исторический фактор развития русского языка. Благодаря им в современной языковой системе органически уживаются фрагменты, иди, точнее, знаки таких динамических подюсов. Уживаются, и оживдяют 
современную русскую речь и литературный язык. Характерным в этом отношении можно назвать «неисторический роман» моего соотечественника, петербургского филолога и писателя Евгения Германовича Водолазкина «Давр» (Москва: АССР, 2014), получившего за него премию «Большая книга». Герой этой книги - средневековый врач и монах, который не смог спасти свою воздюбленную и принявший решение пройти земной путь за неё так, чтобы жизнь его превратилась в житие. Смешивая разные эпохи и языковые стихии, писатель тем не менее оправданно рассчитывает на понимание текста романа современными читателями. Взаимодействие старого и нового здесь очевидно уже и потому, что неожиданное для многих русских стремительное возвращение из марксистского атеизма в христианское православие сделало давно забытое древнерусское языковое прошлое новым настоящим. И в двух фрагментах романа этот языковой симбиоз или, точнее, гибридизация, отражен в полной мере. Но главное - этот гибрид хорошо понимается современным читателем, отдалённым и отделенным от героя романа почти полутысячелетним пространством и ма́стерской стилизацией под него.

Для истории русского языка особо актуадьными явдяются оппозиция и взаимодействие книжной и речевой стихий, кодичественные и качественные пропорции которой были раздичными в разные эпохи его развития. Для истории современного русского литературного языка с эпохи Петра Первого до наших дней эта оппозиция была судьбоносной. В XVIII-м веке петровские преобразования, с одной стороны, открыди «окно в Европу», а с другой - растворили шлюзы русской народной речи, которая мощно хлынула в литературу того времени и обогатила её языковые сокровищницы. Особо мощным оказался, как показали в своих исследованиях М.Ф. Палевская (1973, 1980) и А. Бирих (Bierich 2005) фразеологический «прорыв» в русский литературный язык того времени. В едином ряду со старославянизмами, европеизмами (особенно германизмами и галлицизмами), книжными фразеологическими единицами, оборотами из деловой речи и канцелярита того времени здесь полноправное место заняли разговорные, просторечные и диалектные устойчивые словосочетания. Заняли и это место уже не уступали в последующие периоды истории современного литературного языка. Вот лишь небольшая «горсточка» таких выражений, доставшихся нам из этого периода: андронь едут, булавка в голове, за семь вёрст киселя хлебать, одержать верх, вывести на чистую (свежую) воду, толочь воду [в ступе], висеть на волоске, дать волю, насказать воробья на сосне, попасть впросак, всякая всячина, без году неделя, сложить голову, поити в гору, съесть гриб, красная девица, не робкого (не трусливого) десятка, плясать под чужую дудку, ни копейки за душой, задеть за живое, за тридевять земель, во всю ивановскую, на одну колодку, ещё о конь не валялся, курам на смех, дрожать как осиновый лист, на дружеской ноге с кем, водить за нос кого, нести околесицу, идти на попятныи, пороху не хватает кому, 
семь пятниц на неделе, из рук в руки, ни рыба ни мясо, два сапога пара, показать товар лицьом, трын-трава, бежать как угорельй и др. Многие из них из речевой периферии прорвались в самый центр литературного употребления, окрашивая его всеми стилистическими красками.

Вдияние народной речи на русский дитературный язык всё более усиливалось и достигло апогея в эпоху его национального расцвета начала XIX века. Известно, что писатели XVIII-го века создали основу для такого расцвета. В XIX-м же веке синтез народной речи с речью литературной стал органичным и такие классики этого периода, как И.А. Крылов, А.С. Грибоедов и А.С. Пушкин были творцами этого синтеза. Сплав этих потоков русской языковой системы стал настолько неразрывным, что многие слова и выражения, выхваченные писателями из горнила народной речи, кажутся нам авторскими и заносятся в кладовую крылатых оборотов. И тогда необходим специальный дингвистический анализ, чтобы показать и доказать их народные, речевые истоки. Такая методика основана на точной фиксации хронологии и локализации тех фразеологизмов и пословиц, которые традиционно приписываются конкретным авторам, а также межъязыковым сопоставительным анализом. Материалом для такого исследования стали словари русской народной фразеологии и паремиологии, составляемые нами (Мокиенко, Никитина 2008, 2008а; Мокиенко, Никитина, Николаева 2010) и «Полный фразеологический словарь русских народных говоров», работа над которым нами ведётся в рамках проекта по гранту НФР. Разграничение же «Своего и Чужого» позволяют сделать как словари русских крылатых слов (Берков, Мокиенко, Шулежкова 2000, 2008-2009), так и историко-этимологические словари русской и немецкой фразеологии (Бирих, Мокиенко, Степанова 1998, 2007; Вальтер, Мокиенко 2008), в которых делается попытка установить источники заимствования соответствующих языковых единиц.

Покажем на нескольких примерах крылатых слов и выражений И.А. Крылова, как определяется их конкретный источник языковой источник. Известно, сколь глубокую печать народности оставил в русском литературном языке начала XIX-го века И.А. Крылов. Многие его крылатые слова стали хрестоматийными, изучаются в школах и постоянно цитируются в нашей дитературе и самых современных средствах массовой информации. В нашем «Большом словаре крылатых слов русского языка» (Берков, Мокиенко, Шулежкова 2000; 2008-2009) описано и истолковано 71 наиболее известное крылатое выражение, принадлежащее нашему баснописцу:

[А] воз и ныне там; А вы, друзья, как ни садитесь, / всё в музыканты не годитесь; А где пастух дурак, там и собаки дуры; Ай, моська! знать, она сильна, / что лает на слона; А ларчик просто открывался; Ахнуть не успел, / Как на него медведь насел; Беда ещё не столь большой руки; Беда, коль пироги начнёт печи сапожник, / а сапоги тачать 
пирожник; Без драки попасть в большие забияки; Бросать/бросить щуку в реку; Великий зверь на малые дела; Вертеться [крутиться] как белка в колесе; Видит око, да зуб неймёт; Власть употребить; Ворона в павлиньих перьях; дело мастера боится; Демьянова уха; Дразнить гусей; Жемчужное зерно [в навозной куче]; За что же, не боясь греха, / Кукушка хвалит Петуха? [ За то, что хвалит он Кукушку]; Зелен виноград; 3ло ещё не так <не столь> большой руки; Иван кивает на Петра, а Пётр кивает на Ивана; Избави Бог и нас от этаких судей; Из дальних странствий возвратясь; И моего хоть капля мёду есть; Какой бы шум вы все здесь подняли, друзья, / Когда бы это сделад я!; Как под каждым ей дистком / Был готов и стол, и дом; Когда в товарищах согласья нет [, на лад их дело не пойдет]; Кто посмирней, так тот и виноват; Лебедь, рак и <да> щука; Дето красное пропела; мартышка и очки. мартышка с очками; Мартышка к старости слаба глазами стала; Мартышкин труд; Медвежья услуга; Наделала синица славы, / А моря не зажгла; Наши предки Рим спасли; Не здешнего прихода; Ни пава ни ворона; Аьвиная доля; Одна ласточка весны не делает; Первая ласточка; Орест и Пилад; От <с> младых <молодых> ногтей; Орлам случается и ниже кур спускаться, / Но курам никогда до облак не подняться; Отколе, умная, бредёшь ты, голова?; От радости в зобу дыханье спёрло у кого; Охотно мы дарим, / Что нам не надобно самим; Пой лучше хорошо щеглёнком, чем дурно соловьём; Полают да отстанут; По мне, уж лучше пей, да дело разумей; Пустая бочка громче <больше, звонче> гремит; [Лебедь рвётся в облака,] рак пятится назад [, а щука тянет в воду]; Римский огурец. Огурец с гору; Рыльце в пушку <пуху> у кого; Рядиться в чужие <павдиньи> перья; С волками иначе не делать мировой, / как снявши шкуру с них долой; Сильнее кошки зверя нет; Слона-то [я] и не приметил; Спой, светик, не стыдись; Тришкин кафтан; Ты виноват уж тем, что хочется мне кушать; Ты всё пела? это дело: / так поди же попляши; Ужимки и прыжки; Уж сколько раз твердили миру...; У сильного всегда бессильный виноват; Услуждивый дурак опаснее врага; Фаля; Чем кумушек считать трудиться [, / Не лучше ль на себя, кума, оборотиться]; Что сходит с рук ворам, за то воришек бьют.

Целенаправленное же лексикографическое описание «крыловизмов», учитывающее не только центр, но и периферию их употребления в классике и современном русском языке, в несколько раз повысило их количество. Об этом свидетельствует большой и малый словарь крылатых слов и выражений русского баснописца, которые мы выпустили к его 200-летнему юбилею (Мокиенко, Сидоренко 2013; 2017). И работа над этими словарями показала, что в языке одного из основателей русского литературного языка органично переплетаются результаты действия тех лингвистических оппозиций, о которых выше говорилось. Европейская басенная традиция, восходящая к Эзопу, Лафонтену и другим авторам басенного творчества была успешно воспринята и развита И.А. Крыловым. Но оппозиция «Своё - Чужое», разумеется, не могла быть динамизатором русского литературного языка без живительного потока собственно русской народной речи. И «дедушка Крылов» черпал из этого неистощимого источника и творческое вдохновение, и истинно народные слова и обороты, делая их крылатыми, авторскими.

Выявляя первоисточник басенного сюжета и крылатого выражения, приписываемого русскому баснописцу, надо иметь в виду возможность и 
заимствований, и переделок известных языковых единиц на «крыловский лад», и обращение к животворному источнику народной речи.

Первый случай - пословица Одна ласточка веснь не делает «Нельзя делать вывода, обобщения на основании какого-л. одного случая, незначительного события» и выражение первая ласточка «первые признаки чего- $\lambda . »$, с которыми русские читатели знакомятся со школьных лет по басне И.А. Крылова «Мот и Дасточка» (1818). В ней повествуется о легкомысленном юноше, который продал всё, кроме плаща, а потом, увидев ласточку, продал и плащ, понадеявшись на приход весны. Грянул, однако, мороз, и легкомыслие было наказано, а беспечный юноша виния в своих несчастиях замёрзшую ласточку. Многие русские «крылатологи» и «крылововеды» связывают пословицу и фразеологизм о ласточке с басней И.А. Крылова и почти все при этом указывают на общеевропейский источник басенного сюжета, восходящий к Эзопу (Aesop. fab. 304 Михельсон 1902: I, 735; Ашукины 1966: 474-475; Берков, Мокиенко, Шулежкова 2000: 341 и др.). И действительно: и древнегреческий прототип со строкой из басни Эзопа, повторенный таким авторитетом, как

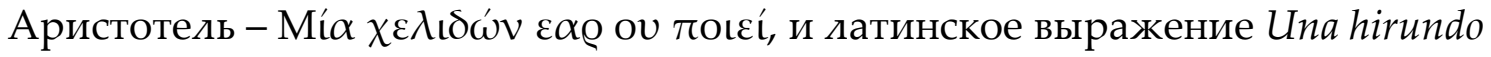
non facit ver! «Одна ласточка весны не делает!» давно уже прочно освоены всеми европейскими языками. Пословица получила широкое распространение как во всех славянских языках (Котова 2000: 80), напр., укр. Одна ластівка не робить весни (весни не робить); польск. Jedna jaskótka nie czyni wiosny (lata); болг. Една лястовица пролет не правя; так и в других европейских: англ. One swallow makes no (does not make) a summer; нем. Eine Schwalbe macht noch keinen Sommer; франц. Une hirondelle ne fait pas le printemps; исп. Una golondrina no hace verano, каталанск. Una oreneta no fa estiu, ит. Una rondine non fa primavera и др. Известность этой пословицы далеко за пределами индоевропейского языкового ареала - напр., в турецком, вепсском, лапландском и японском делает её универсальной. Показательно и межъязыковое пересечение таких её синонимов, как «Один цветок не делает весны (лета)» (албанск., армянск., бельгийск., венг., ит., португальск., рето-романск., румын., турецк., перс.) или «Один цветок не делает гирлянды» (датск., англ., фр., нем., ит., норв., пол.). Paczolay 1997, 49-53. Как видим, русский баснописец, создавая басню «Мот и Яасточка», ориентировался на античную европейскую традицию, воспроизводя этот сюжет живым народным языком.

Вот начало этой басни, никак не напоминающее античные реалии:

\footnotetext{
Какой-то молодец,

В наследство получа богатое именье,

Пустился в мотовство и при большом раденье

Спустия всё чисто; наконец,

С одною шубой он остался,

И то Аишь для того, что было то зимой -

Так он морозов побоялся.
} 
Но, Ласточку увидя, малый мой

И шубу промотал. Ведь это все, чай, знают,

Что ласточки к нам прилетают

Перед весной...

Такие слова, как молодеи, мотовство, раденье, шуба явно отражают истинно русские реалии, не говоря уже о знаменитых русских трескучих морозах. Всё это - элементы русского быта, привнесённые в древний Эзопов сюжет И.А. Крыловым. Народная речь здесь, так сказать, «оконтурила» интернациональную идею, заложенную в эту басню. Но и пословица, и фразеологизм о ласточке остались интернационализмами и их след во всех европейских языках столь же глубок, как и в русском.

Второй случай - когда сюжет басни И.А. Крылова остаётся интернациональным, но крылатое выражение, созданное на этой сюжетной канве, является несомненно русским, с характерной народной речевой маркировкой. К этому типу выражений можно отнести, например, оборот Спой, светик, не стылись. Это крылатая фраза из басни И. А. Крылова «Ворона и лисица» (1808). Аисица обращается к Вороне:

Спой, светик, не стыдись. Что ежели, сестрица,

При красоте такой и петь ты мастерица,

Ведь ты была б у нас царь-птица!...

Это выражение построено на русской фольклорной символике, где Светик мой! Свет очей моих! и под. давно уже бытуют в народной речи как ласковые эпитеты-обращения (Михельсон 1994: 2, 230; Берков, Мокиенко, Шулежкова 2000: 472). Но во фразе, созданной баснописцем, слово светик приобретает специализированную функцию - функцию просьбы, обращённой к кому-либо. И такое употребление сохраняет свою актуальность и в современном русском языке, активно используясь и в живой речи, и писателями, и журналистами: Слушай, Броня, - сказал Андрей, -спой нам что-нибудь, а то Веня заснёт за рулём. - Правда, Буська, спой, только что-нибудь бравурное, весёлое, а то я и вправду засну! - Ну вот ещё, пусти лучше меня за руль! - Никогда! Женщина за рулём - враг человечества! Спой, светик, не стьдись. (Е. Вильмонт. Гормон счастья и прочие глупости).

Третий случай - использование И.А. Крыловым собственно народных пословиц и поговорок, но в именно его баснях обретших статус «крылатости». Такого рода афоризмы И.А. Крылова стали популярными, «вошли в пословицу» именно потому, что и до их употребления русским баснописцем они были уже известны как народные пословицы. Нередко и сам И.А. Крылов подчёркивал их народность типичными глоссами «недаром говорится», «хоть говорят», «как водится» и т.п. Некоторые из таких глосс хотя и имплицитно, но достаточно определённо отсылают именно к давно уже устоявшейся народной мудрости. К такого рода 
«крыловизмам» относится и старая пословица А дуги гнут с терпеньем и не вдруг (Мокиенко 2011).

В басне «Трудолюбивый медведь» (1818) описываются последствия действий напролом, когда без профессионализма и опыта даже мощная сила, «трудолюбие» и энергичные действия приносят лишь вред.

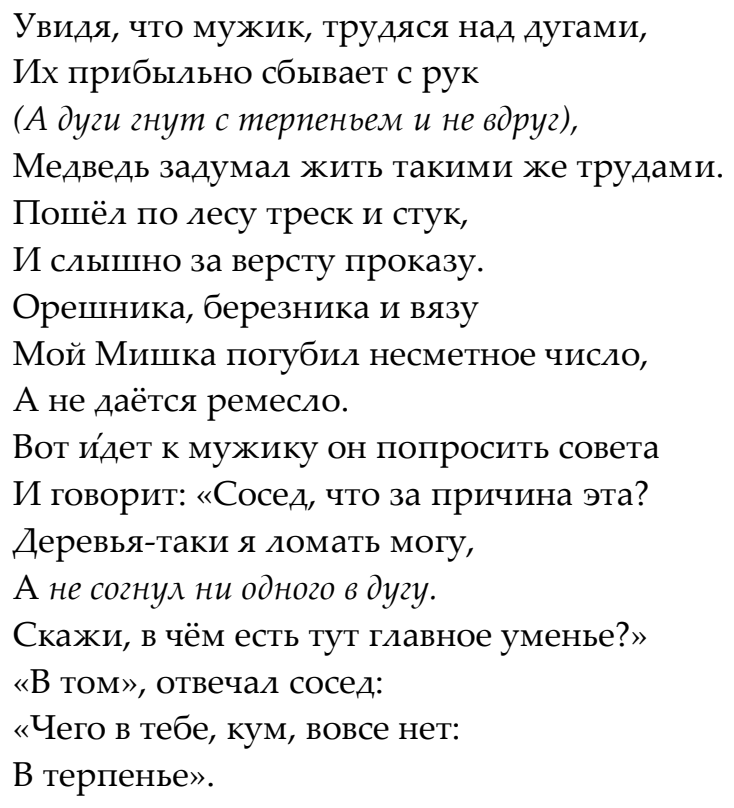

Крылатую пословицу И.А. Крылова М. И. Михельсон поместил под паремиологической вокабулой Исподволь и одьху согнешь, а вкруте и вяз переломишь (Михельсон 1994: I, 382), одновременно предлагая читателю заглянуть (с помощью пометы См.) и на вокабулы Терпенье и Согнуть в дугу. Возможно, что на сопряжение этих двух пословиц автора русского фразеологического тезауруса «навела» книга В. Кеневича «Библиографические и исторические примечания к басням Крылова (Кеневич 1869, 1878: 192), первое издание которой вышло за четверть века до публикации словаря М.И. Михельсона. Именно на эту книгу ссылается советский фодьклорист С.Ф. Елеонский, подчёркивающий вдияние русского фольклора на творчество баснописца: «Пословицы, поговорки и прибаутки он [Крылов] черпал не столько из книг, сколько непосредственно из уст народа, и широко пользовался ими в словесной живописи своих басен (в частности, при создании образов зверей, например пукавой Аисицы или трудолюбивого Медведя; ср. пословицы: <...> «правит, как медведь в лесу дуги гнет», «гнет - не парит, а переломит - не тужит», «Исподволь и ольху согнешь, а вкруге и вяз переломишь» (Елеонский 1956: 239).

Этот ряд пословиц, действительно, хорошо демонстрирует ту паремиологическую модель, по которой выстроена и басня И.А. Крылова, и крылатая фраза А дуги гнут с терпеньем и не вдруг. Не случайно и вся эта пословичная «троица» отражена в тезаурусе М.И. Михельсона в достаточно 
большой вокабуле Гнет - не парит, переломит - не тужит. Живет не тужит, по свету кружит. Лес по дереву не тужит (иноск.) - идти напролом (ради достижения цели) и иллюстрируется литературными контекстами (Михельсон 1994, I: 200):

Ср. Справедливо гласит русская пословица: судьба гнет не тужит, переломит... Тургенев. Несчастная. Ср. Какое немножко (самодуроват)! В Сибири-то живет, привык словно медведь в лесу, по пословице: гнет - не nарит, сломает - не тужит. Писемский. Мещане. Ср. И рожа-то у канальи, как у аспида, по пословице: гнет дуги - не парит, сломает - не тужит. Писемский. Тысяча душ. Ср. Царь этот царствовал, как медведь в лесу: дуги гнет, гнет не парит, переломит, не тужит. Даль. Сказка первая о Иване (Царь Дадон).

Эту пословицу - единственную из серии пословиц о «дуге» включил в свой словарь и В.П. Жуков, предлагая такую её дефиницию: «Действует напролом. Говорится о ком-л., кто поступает ни с кем и ни с чем не считаясь, не жалея никого» (Жуков 1991: 85). При этом им воспроизводятся (по М.И. Михельсону) контексты из А.Ф. Писемского и В.И. Даля и добавляется одна илдюстрация из Н.С. Аескова. В таких контекстах «упакована» и пословица с «главным героем» басни И.А. Крылова: привык словно медведь в лесу и цุарствовал, как медведь в лесу. Пословицу же Исподволь и ольху согнёшь, а вкруте и вяз переломишь М.И. Михельсон прямо увязывает с фразой баснописца.

Собственно, внимательно перечитывая басню, легко ощутить не только её мотивацию, но и найти «сюжетные линии» этих пословиц. Так, противопоставление ломкой ольхи гибкому и «гнучему» вязу намечено в басенном перечислении деревьев по степени их гибкости: «Орешника, березника и вязу...». Следовательно, нащупанная В. Кеновичем и С.Ф. Елеонским паремиологическая модель, по которой создана басня, объективна. Именно из названных пословиц и устойчивого сравнения гнуть/ согнуть в дугу, видимо, И.А. Крылов и создал свой афоризм, который двести лет назад приобрёл также статус пословицы.

Источники этих пословиц позволяют определить их пространственный и временной диапазон и продемонстрировать их вариантность в народной речи. Пословицы и поговорки о процессе «гнутья дуг» весьма полно отражены в нашем фольклоре и детально паспортизированы в трехтомном их собрании (Мокиенко, Никитина 2008; Мокиенко, Никитина 2008а; Мокиенко, Никитина, Николаева 2010).

Сюжет о том, как гнёт дуги «хозяин леса» нашёл отражение в таких паремиях, как Иной правит как медведь в лесу дуги гнёт (Ан. 1988: 120); Медведь дуги гнул, да запрягать не во что (Аникин 1988: 175); как медведь в лесу дуги гнуть 'о человеке, делающем что-л. тяжеловесно, неловко, с силой', 'о человеке, догматически и упрямо гнущем свою линию' (Даль 1957: 428, 487); как медведь в лесу дуги гнёт: гнёт - не парит, переломит - не правит 'о 
человеке, догматически и упрямо гнущем свою иинию' (Зимин, Спирин 1996: 218); правит как медведь в лесу дуги гнёт [: гнёт - не парит, а переломит не тужит] 'о человеке, делающем что-л. тяжеловесно, неловко, с силой' (Даль 1957: 226; Даль 1955: II, 312; Зимин, Спирин 1996: 65).

Немало в нашем фольклоре и пословиц, хранящих память о том, из каких именно пород деревьев гнули раньше дуги, а какие для этого промысла не пригодны из-за ломкости. Здесь мы находим прежде всего главную «древесную оппозицию», отраженную в пословицах, приводимых исследователями басни И.А. Крылова как её потенциальные источники гибкий и потому идеально подходящий для изготовления дуг вяз и домкая ольха:

Исподволь и ольху согнёшь (Рыбникова 1961: 118); Исподволь и ольху согнёшь, а вкруте (в круте) и вяз переломищь (Петр. галер. нач. XVIII в. 1961: 28; Татищев нач. XVIII в. 1961: 54; Барсов 1770: 89; Курганов 1777: 112; СЛРЯ XVIII: III, 188; Снегирев 1848: 151; Даль 1957: II, 143; Даль 1955: I, 211; Даль 1955 II, 54, 203; Даль 1955: III, 63; Аникин 1988: 120); Исподволь и ольху согнёшь, а круто и вяз переломишь (Соболев 1956: 149); Исподволь и ольха гнётся, а вкруте и вяз ломится (Богданов 1741: 84); Исподтиха и олешка (т.е. небольшое ольховое дерево) гнётся (волог. - СРНГ: ХІІ, 234-235) и др.

Находим в ряду этой паремиологической модели и упоминание об одном из деревьев, «погубленных» ретивым медведем, - берёзе, которая благодаря её гибкости использовалась для изготовления дуг так же, как и вяз. Характерно при этом, что эта пословица записана на русском Севере, где берёзу гнули на дуги из-за отсутствия вяза: Вкруте (т.е. второпях, быстро, поспешно; вдруг) берёза ломится, а исподоволь (т.е. исподволь) и ольха гнётся (СРНГ 12: 234). Ср. также пословицу, где вяз противопоставлен лутошке, т.е. липе, с которой содрали кору, из-за чего она сохнет, чернеет и теряет гибкость: Вкруте и вяз ломается, исподволь и лутошка гнётся (Аникин 1988: 46).

«Секрет производства» дуг, закдючавшийся в терпеливом и длительном сгибании подходящей древесины, которую для этого даже специально пропаривали, отразился и в серии пословиц, где терпеливое сгибание будущей дуги противопоставлено торопливому стремлению к результату, из-за чего дерево ломается. Большинство из них иронически характеризуют неумелого и недобросовестного ду́жника, т.е. мастера, гнущего дуги:_Геёт - не парит, а изломит - не тужит (Татищев нач. XVIII в. 1961: 50); Гнёт - не парит, [a] переломит - не тужит (Петр. гал. нач. XVIII в. 1961: 25; Даль 1957: I, 334; Даль 1955: I, 362; Михельсон 1994: I, 200; Аникин 1988: 243).

Часть из них - это рекомендации избегать «перегибов» при изготовлении дуг: Круто гнёшь - переломишь (Аникин 1988: 145); Гни, поколе не треснет (Даль 1957: II, 146; Даль 1955: I, 362); Так гни, чтоб (чтобы) гнулось, 
а не так, чтоб (чтобы) лопнуло (Даль 1957: II, 146; Даль 1955: I, 362; Разумов 1957: 38; Аникин 1988: 298); Из дуги оглобли не сделаешь (Даль 1955: I, 499; Разумов 1957: 126; Жигулев 1969: 52; Аникин 1988: 117).

Ср. также пословицы, где процесс сгибания дуги становится метафорой-характеристикой покладистого, уступчивого поведения человека; Аучше гнуться, да не переломиться (Танчук 1986: 81; Аникин 1988: 167); Аучше гнуться, чем переломиться (Даль 1957: I, 161; Даль 1955: I, 362; Танчук 1986: 81).

Из таких пословиц, собственно, и выросла басня И.А. Крылова, в которой Медведь грубо нарушил все правила «правления дуг» и тем самым стал ярким символом нетерпеливого бракодела. Характерно, что многие из названных пословиц были зафиксированы уже в XVIII веке, - в том числе и в сборнике пословиц А.А. Барсова (1770), который был нашему баснописцу хорошо известен.

Значимой для басни, разумеется, была и поговорочная семантика дуги, которая здесь эксплицитно выражена:

Деревья-таки я иомать могу,

А не согнул ни одного в дугу.

Сравнение согнуть в дугу (в три дуги) давно уже в русском языке приобрело переносные значения и употребляется в разных вариантах: прост. гнуться в дугу (в три дуге) 'очень низко (согнуться)'; гнуть/ согнуть в дугу (в три дуги) кого 'принуждать, заставдять кого-л. подчиняться, повиноваться', 'причинить зло кому-л.'; волгоград. гнуть в три дуги кого 'добиваться от кого-л. полного подчинения, покорности'; прост. гнуть дугу не по себе 'браться за непосильное дело'.

Из широкого ряда приведённых пословиц и поговорок в современном русском языке, пожалуй, осталось в активном употреблении лишь сравнение согнуть в дугу кого. Не случайно оно известно и другим восточнославянским языкам: бел. гнуцьљ/ сагнуць у дугу; укр. гнути/ зігнути в дугу, гнути/ зігнтти в три дуги. При этом его прямая семантическая связь с процессом изготовления важного элемента конской упряжи настолько забылась, что некоторые историки русского языка связываю его со старинной пыткой - когда допрашиваемому привязывали голову к ногам веревкой, в которую вдевали палку и вертели ее до тех пор, пока голова не пригибалась вплотную к ногам (Ермаков 1894: 45-46; Илдюстров 1915: 303; Максимов 1955: 36). Однако, именно знание деталей изготовления дуг, которые нужно было сгибать терпеливо, осторожно и неторопливо исподьзуя силу, приводит к выводу, что и эта поговорка - прямое отражение «дужного» ремесла (Бирих, Мокиенко, Степанова 2005: 204). И басня И.А. Крылова, в которой она органически вписывается в сюжет о дужнике-бракоделе Медведе, - одно из неоспоримых свидетельств её 
ремесленного, а не «пыточного» происхождения. Благодаря басне в нашей памяти с детства закрепилось и представдение о некогда весьма нужном и известном, а ныне забытом процессе изготовления дуг. И это представление и некогда значимом народном крестьянском ремесле благодаря нашему баснописцу дожило до нашего космического и интернетного времени. Дожило, как яркий знак народности басен И.А. Крылова и симбиоза речевой и фольклорной стихии в его творчестве.

Этот симбиоз органичен и для творчества А.С. Грибоедова. Современный литературный язык унаследовал из его комедии «Горе от ума» 71 крылатое выражение, которые активно употребляются и современными русскими. Наш словарь крылатых слов произведений поэта, однако, показывает, что это наследие более чем десятикратно превосходит это число: в нем более 800 словарных статей (Мокиенко, Семенец, Сидоренко 2009, 2009а). И уже их простое перечисление показывает, что взаимодействие книжного, общеевропейского и народного, собственно русского, в этом наследии столь же органично. Вот несколько таких крылатых выражений:

Дистанциия огромного размера; А горе ждет из-за угла; А судьи кто?; И в воздух чепчики бросали; Минуй нас пуще всех печалей и барский гнев, и барская любовь; Не должно сметь свое суждение иметь; Нельзя ли для прогулок подальше выбрать закоулок?; От головы до пяток на всех московских есть особый отпечаток..

Среди таких языковых единиц находим и такие, которые восходят к античной культуре Европы - как, например, пословица И дым отечества нам сладок и приятен. Она восходит к латинской пословице Et fumus patriae dulcis; Dulcis fumus patriae (букв. «И дым Отечества сладок»; «Дым Отечества сладок»). Аналогичные изречения встречаются и в «Одиссее» Гомера: «...Видеть хоть дым, от родных берегов вдалеке восходящий...». В русском языке эта пословица появдяется, видимо, в 70-е гг. XVIII в., когда в России увеличивается интерес к античности. Она употребляется у Г.Р. Державина, П.А. Вяземского, К.Н. Батюшкова. Но именно благодаря употреблению пословицы в комедии «Горе от ума» (1822-1824) А.С. Грибоедова она получила широкую известность.

Примером же активизации народной речевой стихии в творчестве А.С. Грибоедова можно назвать краткое экспрессивное выражение глухая тетеря.

Его употребляет Фамусов:

Ты, Филька, ты прямой чурбан.

В швейцары произвёл ленивую тетерю,

Не знает ни про что,

Не чует ничего.... 
Со школьного прочтения комедии А.С. Грибоедова мы помним эти строки и органически сопрягаем выражение ленивая тетеря в ассоциативный ряд с двумя другими - глухая тетеря и сонная тетеря. Оно нам кажется столь же естественно народным, общеречевым, как и характеристики глуховатого и сонливого. Между тем жизнь ленивой тетери дал именно автор «Горя от ума», превратив этот оборот в крылатую характеристику неповоротливого и ленивого слуги Фамусова.

Во фразеологии, как известно, часто сохраняются языковые «окаменелости» разного рода - устаревшие слова и их формы, редкие специальные термины или собственные названия, диалектизмы, не попавшие в фонд литературного языка. $\mathrm{K}$ последним относятся и выражения глухая тетеря, ленивая тетеря и сонная тетеря. Так же, как диалектное обозначение русского муравья - мурашка, закрепившееся дишь в составе фразеологизма мурашки бегут по коже, и слово тетеря в отличие от тетерев стало специализированной фразеологической метафорой для характеристики глухого, ленивого или сонного, вялого человека. Собственно, именно благодаря вхождению в состав фразеологизмов, оно значительно расширило масштабы своего распространения. И в литературном языке три грубо-просторечных оборота с диалектизмом тетеря давно уже употребляются многими писателями.

Пальму первенства по употребительности занимает выражение глухая тетеря - 'глухой, ничего не слышащий человек', имеющее корни с XVIII веке. Оно регистрируется многими словарями и в контекстных илдюстрациях четко проступает шутливо-бранный характер выражения, которым так раздражительно укоряют плохо слышащего.

Показательно, что хотя в XIX в. и возникла возможность «олитературить» этот оборот, т.е. «перевести» тетерю в тетерева, такой вариант так и не прижился в последующих литературных употреблениях, оставшись, в сущности, фразеологическим знаком индивидуального стиля.

Популярность и трёхвековая устойчивость оборота объясняются прежде всего культурными факторами и традиционным русским бытом. Тетеревиная охота издавна популярна в лесной полосе европейской России и Сибири. Семейство тетеревиных, в которое входят, кроме тетеревов, рябчики, глухари и другие птицы, ценно в промысловом отношении. В выражении глухая тетеря речь идёт о так называемом глухом тетереве, который, по наблюдениям охотников, во время токования, т. е. брачного пения, привлекающего самок-тетёрок, не слышит ничего вокруг. Именно поэтому тетеревиный ток (место токования тетеревов) привлекает особое внимание охотников: легко незаметно приблизиться к птицам.

Таким образом, доминирующим значением метафорического употребления слова тетерев является признак «глухота». Она в бытовом сознании нередко связывается с бестолковостью, глуповатостью - не случайно М.И. Михельсон дал нашему выражению синкретическое 
определение - «глухой, тупой человек, бестолковый». Он объясняет и логику перехода от глухоты к сондивости, приведя сравнение глух как тетерев [во сне] (Михельсон 1994: I, 198). И действительно, токующая или сонная птица ничего не видит и не слышит: по народным наблюдениям, Тетереву вся зима - одна ночь (Михельсон 1994: II, 297).

Грибоедовское выражение ленивая тетеря - один из ярких вариантов фразеологического «тетеревиного» ряда. Его прототипическая связь с глухим тетеревом эксплицитно выражена писателем в словах Фамусова «Не знает ни про что, Не чует ничего», где чует имеет значение 'слышать'. В контексте комедии оборот предваряется прямым обвинением ленивой mетери - слуги Фильки в незнании и тупости усилением бранной экспрессии птичьей метафоры прямодинейным сопоставлением с чурбаном. И пусть глухота и глупость не стодь уж прямодинейно связаны с ленью, логика такого перехода вполне понятна. Ведь по древней пословице именно Иень - мать всех пороков, в том числе и трёх «тетеревиных». Возможно, выбор эпитета ленивая А.С. Грибоедовым был подсказан и ритмическими, эвфоническими мотивами: в ритмику стиха прилагательные глухая и сонная не укладываются. Как бы то ни было, а у ленивой тетери А.С. Грибоедова прямого фразеологического предшественника ни в литературном языке, ни в народной речи нет. Это выражение искусно выращено нашим поэтом из двух других известных народных оборотов - глухая тетеря и сонная тетеря. Выращено и продолжает жить благодаря жизненной силе грибоедовской комедии.

Наиболее органичен симбиоз книжной и народно-речевой стихии, конечно же, в творчестве А.С. Пушкина. Современный русский язык унаследовал у А.С. Пушкина «рекордное» количество крылатых выражений, входящих в собрания «крылатики» - 360! А в нашем «Школьном словаре крылатых выражений Пушкина» (Мокиенко, Сидоренко 2005) их число (включая, разумеется, и периферию употребления) достигает почти 3000 крылатых слов и их вариантов. И столь большое количество крылатых пушкинизмов обусловлено именно ролью А.С. Пушкина в истории нашего литературного языка. «В рассуждениях о Пушкине нельзя ограничиться только проблемой литературного языка, пишет В.В. Колесов. - Жизнью, творчеством и посмертной славой поэта определяются все три уровня, или, если угодно, три ипостаси нашего языка: русский язык как система, русский язык как норма, язык русской литературы как совокупность стилей» (Колесов 1999: 63). И во многом такое триединство опирается на народные истоки пушкинского творчества, обогащённые литературной общеевропейской традицией. Эту родь русской обиходной речи в творчестве поэта искдючительно точно подчеркнул Г.О. Винокур: 
«Пушкин создавал свою художественную прозу действительно из того бытового лингвистического сырья, которое находилось в его распоряжении в виде переработанного, свёрнутого в своих потенциальных богатствах, обиходного разговорного зыка... прежде чем стать языком литературы и вместе с тем приобрести значение языка культурного, этот обиходный язык служил для Пушкина предметом творческого преодоления и стилистической обработки именно в этом своем своеобразном качестве, в жанрах обыденной и повседневной речи» (Винокур 1991: 185).

«Бытовое лингвистическое сырьё», русская обиходная речь у А.С. Пушкина подвергается такой искусной художественной шлифовке, что мы не сомневаемся в том, что многие меткие образные выражения созданы именно поэтом. Специальный иингвистический анализ помогает выстроить их актуальность по степени употребительности (Мокиенко 1996): Золотая рыбка, оставаться у разбитого корыта, медный всадник, Мой дядя самых честных правил; Чем меньше женщину мы любим, тем легче (больше) нравимся ми ей; Иных уж нет, а те далече; С корабля на бал; Я вас любил: любовь моя, бьть может, [В душе моей угасла не совсем]; Аюбви все возрасть покорны; Я Вас любил: любовь ещё, быть может [, В дуще моей угасла не совсем]; Народ безмолвствует; Тиха украчнская ночь. Прозрачно небо. Звёзды блещут; Здравствуй, племя младое, незнакомое! Унылая пора! Очей очарованье! ...; Что пройдёт, то будет мило; Темницьь рухнут, и свобода...; Родила цзарицза в ночь/ Не то сына, не то дочь; / Не мышонка, не лягушку, / А неведомую зверюшку.

За каждым из них стоит особая история, особый пушкинский сюжет и особое взаимодействие народной и книжной стихии. Приведу лишь один пример из тех тысяч пушкинизмов, которые нами описаны в словаре крылатых слов А.С. Пушкина - выражение и мхльчики [кровавые] в глазах 'рябит в глазах у кого-л.'. Его обычно возводят к монологу царя Бориса в трагедии А.С. Пушкина «Борис Годунов» (1825):

\footnotetext{
Как молотком стучит в ушах упрёк,

И все тошнит, и голова кружится,

И мальчики кровавые в глазах.
}

Однако Пушкин не был автором этого выражения, а лишь исподьзовал один из вариантов псковского оборота мальчики в глазах «рябит, зеленеет в глазах», обогатив общее значение, характеризующее эмоциональное возбуждение человека, двуплановой ассоциацией с «кровавым мальчиком»- убиенным царевичем Дмитрием.

В диалектах данное выражение имеет много вариантов: угланчики в глазах бегают, мухи (мушки) в глазах; пск. беси с глаз накатятся [у кого] 'о состоянии человека после сильного удара'; арх. чёртики забегали в голове [у кого] 'кто-л. потерял возможность нормадьно рассуждать, действовать'; смол. черти из глаз посыпались (посыпятся) у кого 'о крайней степени усталости'; смол. озерки в глазах забегали (будут) 'искры перед глазами'; 
забайкал. живчики в глазах бегают у кого 'о смышленом, живого ума человеке'; укр. зайчики в голові стрибають у когось и под. «Образ» маленького человечка в глазах не случаен: во многих индоевропейских языках, древних и новых, зрачок и ребенок-подросток называются одним и тем же словом. Ср.: смол. (1914) мальчик 'зрачок': «Девка, что-то не видит махьчик - глаз мой нешто спортился» (СРНГ 1965-2007: XVII, 345).

Выражение кровавые мальчики в глазах нельзя трактовать как конкретный призрак, преследующий царя-убийцу, ещё и потому, что слово мальчик родилось в сфере народной речи, в начале XVIII в. оно ещё не стало литературным и не могло употребляться по отношению к образу царевича. В качестве книжного синонима употреблялось существительное отрок. Прил. кровавый в этом обороте имеет значение «красный, багровый, цвета крови», а не «окровавленный». Выражение мальчики в глазах характеризует физическое состояние Бориса (дурнота, недомогание, то, что мерещится), компонент кровавые несет в себе глубокий симводический смысл, характеризуя больную совесть царя, на которой лежит пятно кровавого цвета. По народным поверьям, красные глаза либо же перевернутые «мальчики» в глазах нередко бывали у колдунов.

Таким образом, народное выражение получило новую жизнь в трагедии А.С. Пушкина «Борис Годунов», хотя было известно народной речи гораздо раньше. (Мокиенко 1979: 22-24; Мокиенко 1980: 16-17; Сорокин 1983: 129-135). Но именно благодаря поэту оно из «чекана народности» (В.И. Даль) обрело литературную жизнь и стало крылатым.

Популярность крылатых слов и выражений русских классиков и в наши дни во многом обусловлена тем исконным взаимодействием речевой и книжной стихии, которое я пытался продемонстрировать в своём докладе. Угадывание их народного истока и есть обычно той самой «скрепой» языковой памяти, которая не только обеспечивает их популярность, но и рождает активную словесную игру, не дающую классическим выражениям закостенеть в своей недвижимой классичности. Вот несколько примеров такого рода игровых трансформаций крылатых выражений А.С. Пушкина, описанных в нашем с Х. Вальтером словаре «Антипословицы русского народа» (Вальтер, Мокиенко 2005):

\author{
Дюбви все возрасты покорны: \\ В любви все возрасты проворны; \\ Аюбви все возрасты покорны, но только органы не все; \\ Я Вас пюбил: любовь ещё, быть может [, В душе моей угасла не совсем]: \\ Я Вас любил, деревья гнулись. \\ Народ безмодвствует: \\ Народ безмолвствует всё громче! \\ Унылая пора! Очей очарованье!... \\ Унылая, пора... \\ Что пройдёт, то будет мидо.
}


Что пройдёт, то будет мимио.

Темницы рухнут, и свобода...

Темницьь рухнут на светлицьь.

Конечно, не все такие языковые «приколы» можно отметить «знаком качества» и приписать им литературные достоинства. Но креативный их характер несомненен, а такие антипоговорки, как Народ безмолвствует всё громче, хочется думать, одобрил бы и сам А.С. Пушкин, не раз в своей жизни как раз и пострадавший за народное безмодвствие. Главное же - и самые неудачные переделки крылатых слов классиков русской литературы свидетельствуют о том, что народ знает свою классику и хранит её в своей памяти со школьных лет, воспроизводя в виде популярных цитат. Так народные истоки образного языка русской дитературы не только продолжают жить, но и становятся всё полноводнее, обогащаясь и современной разговорной речью, и современными литературными произведениями, и динамичными средствами массовой информации.

БИБЛИОГРАФИЯ

BIEIRCH, A. (2005), Russische Phraseologie des 18. Jahrhunderts. Entstehung, Semantik, Entwicklung. (= Heidelberger Publikationen zur Slavistik. A. Linguistische Reihe. Band 16. Hsg.: Baldur Panzer), Frankfurt am Main-Berlin-Bern-Bruxelles-New YorkOxford-Wien.

PaczOlAy, G. (1997), European Proverbs in 55 languages with equivalents in Arabic, Persian, Sanskrit, Chinese and Japanese. Veszprem, Nyomda Rt.

АнИкИН, В. П. (1988), Русские пословиць и поговорки, Москва, Художественная литература.

БАРСОВ, А. А. (1770), Собрание 2491 древних российских пословии, Москва.

АшукИН, Н. С.; АшуКИНА, М. Г. (1966), Крылатые слова. Аитературные цุитаты. Образные выражения, Москва, Художественная дитература.

БЕРКОВ, В. П.; МОКИЕНКО, В. М.; ШУ АЕЖКОВА, С. Г. (2000), Большой словарь крылатых слов русского языка, Москва, Русские словари, ООО Издательство Астрель, ООО Издательство АСТ.

БЕРКОВ, В. П.; МОКИЕНКО, В. М.; ШУ ЛЕЖКОВА, С. Г. (2008-2009). Большой словарь крылатых слов и выражений русского языка: ок. 5000 ед.: в 2-х т., Магнитогорск, МаГУ; Greifswald, Ernst-Moritz-Arndt-Universität.

БОГдАНОВ, А.И. (1741), Собрание пословиц А.И. Богданова, ППЗ 1961, 65-118; 259263.

ВАЯьтеР, Х.; МОКИЕНКО, В. М. (2005), Антипословиц̨ы русского народа. СанктПетербург, Издательский Дом «Нева».

ВАЯЬТЕР, Х.; МОКИЕНКО, В. М. (2008). Om «A» до «Zwickmühle». Историкоэтимологические комментарии к немецкой фразеологии, Greifswald, ErnstMoritz-Arndt-Universität.

ВинОкур, Г. О. (1991), Пушкин-прозаик, Культура языка, Москва, Высшая школа, 179-195. 
ДАль, В. И. (1955), Толковый словарь живого русского языка, Тт. 1-4. Москва, Иностранных и национальных словарей.

ДАль, В. И. (1957), Пословицы русского народа. Москва, Художественная литература.

ЕлЕОНСКИЙ, С.Ф. (1956), Аитература и народное творчество. Пособие для учителей средней школь, Москва, Гос. уч.-пед. изд. Мин. просв. РСФСР.

ЕРМАКОВ, Н. Я. (1894), Пословицы русского народа. Санкт-Петербург.

ЖиГУЛЕВ, А. М. (1969), Русские пословицы и поговорки. Москва, Наука.

Жуков, В. П. (1991), Словарь русских пословии и поговорок, Москва, Русский язык.

ЗИМИН, В.И.; СПИРИН, А.С. (1996), Пословиць и поговорки русского народа, Москва, Сюита.

ИАЯЮстРОВ, И. И. (1915), Жизнь русского народа в его пословицах и поговорках. СанктПетербург.

КЕНЕВИЧ, В.Ф. $(1869,1878)$, Библиографические и исторические примечания к басням Крылова, Санкт-Петербург.

КОАЕСОВ, В.В. (1999), «Жизнь происходит от слова...», Санкт-Петербург, Златоуст.

КОтОвА, М. Ю. (2000), Русско-славянский словарь пословиц, с английскими соответствиями, Санкт-Петербург, Изд-во СПбГУ.

КуРГАНОВ Н. Г. (1777), Книга писмовник, а в ней наука российского языка с седмъю присовокупленияли, разных учебных и полезнозабавных вещесловий, Новое изд., пересмотренное, поправленное и умноженное, Санкт-Петербург.

МАКСИМОВ, С. В. $(1891,1955)$, Крылатые слова. Санкт-Петербург, Москва, ГИХЛ.

МИХельСОН, М. И. (1994), Русская мыссль и речъ. Своё и чужое. Опыт русской фразеологии. Сборник образных слов и иносказаний, Москва, Русские словари.

МОКИЕНКО, В. М. (1979), Вариантность фразеология и проблема индивидуальноавторских фразеологических единиц, Современная русская лексикография, Ленинград, Наука, 19-26.

МокИенко, В. М. (1980, 1989). Славянская фразеология. Москва, Высшая школа.

МокИЕНКО, В. М. (1996). Крылатые слова А. С. Пушкина в современном контексте, ARION. Jahrbuch der Deutschen Puschkin-Gesellschaft, Band 3, Bonn, Bouvier Verlag, 155-173.

МОКИЕНКО, В. М. (2011). Из культурологических комментариев к басням И.А. Крыдова (А дуги гнут с терпеньем и не вдруг), Русистика и современность, том 1, Аингвокультурология и межкультурная коммуникация, Санкт-

Петербург, РГПУ им. А.И. Герцена, изд-во «Северная звезда», 285-292.

МОКИЕНКО, В. М., НИКИТИНА, Т.Г (2008), Большой словарь русских поговорок. Более 40 000 образных выражений, Москва, ЗАО ОАМА Медиа Групп.

МОКИЕНКО, В.М.; НИКИТИНА, Т.Г.; НИКОЛАЕВА, Е.К. (2010), Большой словарь русских пословии, Москва, ОЛМА Медиа Групп.

МОКИЕНКО, В. М.; СЕМЕНЕЦ, О. П.; СИДОРЕНКО, К. П. (2009), Больนой словарь крылатых выражений А. С. Грибоедова. («Горе от ума»), Москва, ОЛМА Медиа Групп.

МОКИЕНКО, В. М.; СЕМЕНЕЦ, О. П.; СИДОРЕНКО, К. П. (2009а). «Горе от умиа» А. С. Грибоедова: изитаты, хитературные образы, крылатые выражения. Учебныи словарь-справочник, Санкт-Петербург, Изд-во РГПУ им. А. И. Герцена.

МОКИЕНКО, В. М.; СИДОРЕНКО, К. П. (1999). Словарь крылатых выражений Пушкина, 
Санкт-Петербург, Фолио-Пресс.

МОКИЕНКО, В. М.; СИДОРЕНКО, К. П. (2005). Школьный словарь крылатых выражений Пушкина, Санкт-Петербург-Москва, Издательский Дом «Нева».

МОкИЕНКО, В. М.; СИдОРенКО, К. П. (2013). Басни Ивана Андреевича Крылова: ццитаты, литературные образы, крылатые выражения. Словарь-справочник, СанктПетербург, Рос. гос. пед. ун-т им. А.И. Герцена.

МОКИЕНКО, В. М.; СИДОРЕНКО, К. П. (2017). Крылатые выражения, хитературные образы и изитаты из басен Ивана Андреевича Крылова, Москва, Центрполиграф.

НС3-90 (2009-2015), Новье слова и значения. Словарь-справочник по материалам прессы и хитературы 90-х годов, том 1 (А-К), Санкт-Петербург, «Дмитрий Буланин».

ПАЛЕВСКАЯ, М.Ф. (1972), Основные модели фразеологических единиц, со структурой словосочетания в русском языке XVIII века, Кишинёв, Картя Моддовеняскэ.

ПАЛЕВСКАЯ, М.Ф. (1980). Материалы для фразеологического словаря русского языка XVIII века, Кишинев, Штиинца.

ПЕТР. ГАЛЕР. НАЧ. ХVIII ВЕКА (1961), Сборник пословиц, б. Петровской галереи, Пословицы, поговорки, загадки в рукописных сборниках XVII-XX веков, МоскваПенинград, Наука.

ППЗ (1961), Пословицььl, поговорки, загадки в рукописных сборниках XVII-XX веков, Москва; Ленинград, Наука.

РАЗУМОв, А. А. (1957), Мудрое слово: русские пословиць и поговорки, Москва.

РыБникова, М. А. (1961), Русские пословицы и поговорки, Москва, Изд-во АН СССР.

СЛРЯ XVIII в. (1984-2007): Словарь русского языка XVIII в., 1-17, Ленинград (Санкт-Петербург), Наука.

СНЕГИРев, И. М. (1848), Русские народные пословиць и притчи, изданные И. М. Снегиревым с предисловием и дополнениями, Москва.

СОБОлЕв, А. И. (1956), Народные пословицъв и поговорки, Москва, Московский рабочий.

СОРОКИН, Ю.С. (1983), И мальчики кровавые в глазах, Современная русская лексикография, Ленинград, Наука, 129-135.

СРНГ (1965-2007): Словарь русских народных говоров, 1-41 (издание продолжается), Ленинград-Санкт-Петербург, Наука.

ТАНЧук, В. (1986), Сборник пословиц русского языка, Нью-Йорк.

ТАТИщЕВ В.Н. НАЧ. XVIII в.: Сборник пословиц В. Н. Татищева, ППЗ 1961, 47-64; 257-259. 